\title{
Digestibility of energy, protein, fat and non-starch polysaccharides in mixed diets: comparative studies between man and the rat
}

\author{
BY K. E. BACH KNUDSEN ${ }^{1}$, ELISABETH WISKER ${ }^{2}$, MARTINA DANIEL ${ }^{2}$, \\ W. FELDHEIM ${ }^{2}$ AND B. O. EGGUM ${ }^{1}$ \\ ${ }^{1}$ National Institute of Animal Science, Department of Animal Physiology and Biochemistry, \\ Research Centre Foulum, P.O. Box 39, DK-8830 Tjele, Denmark ${ }^{2}$ Christian-Albrechts University of \\ Kiel, Institute of Human Nutrition and Food Science, Düsternbrooker Weg 17-19, D-2300 Kiel 1, \\ Germany
}

(Received 5 February 1993 - Revised 28 May 1993 - Accepted 21 June 1993)

\begin{abstract}
The apparent digestibility of energy, protein, fat and non-starch polysaccharides (NSP) of low and high dietary fibre (DF) mixed diets were studied in three series of experiments with man and the rat. Low DF diets were used as control diets in each experimental series and the DF level was increased by adding fruits and vegetables (Study 1), citrus fibre concentrate (Study 2) and insoluble barley fibre (Study 3). In Study 3 the high DF diet was fed at two protein levels. There was in most cases good agreement between the digestibility of energy between man and the rat, with the digestibility of energy of the low DF control diets of 0.941-0.950 in man compared with 0.933-0.952 in the rat and of the high DF diets of $0.897-0.931$ in man and $0.865-0.920$ in the rat. The biggest difference in digestible energy between the two species was found for the diet enriched with fruits and vegetables $(0.032$ absolute units) and citrus fibre concentrate (0.025 absolute units). Apparent digestibility of protein was slightly lower in man than in the rat for all diets in Studies 1 and 2 . In Study 3, however, apparent digestibility of protein was consistently lower in man than in the rat with differences in absolute digestibilities between the two species varying from 0.023 (high $\mathrm{DF} /$ high protein) to 0.071 (high $\mathrm{DF} /$ low protein). The digestibility of fat was the same in man and in the rat in all but the high DF diet of Study 2. The rat appears to have a lower capacity to digest fibre polysaccharides than man and the digestibility of NSP was consistently lower in the rat than in man. The biggest difference between the two species was found for the diets in Study 2 where the digestibility of NSP in man was measured to be $0.774-0.885$ compared with only $0.501-0.517$ in the rat. For the other diets the differences in NSP digestibility were $0.077-0.137$ absolute units. In spite of some differences between man and the rat in their ability to digest nutrients the various diets are ranked in the same order by the two species.
\end{abstract}

Digestibility: Dietary fibre: Man: Rat

The need for appropriate animal models when studying questions in human nutrition is very great because under many experimental conditions and situations it is difficult or impossible to use human subjects. Furthermore, studies with humans are generally complicated, time-consuming and expensive.

The rat is the most frequently used animal model for studying digestibility in humans and much valuable information is produced using the rat in such studies (Food and Agriculture Organization/World Health Organization (FAO/WHO), 1991). The great value of the rat model is the low cost associated with relatively simple research facilities and turnover. This allows the use of large numbers of animals and rapid production of results. One major advantage is that the rat is omnivorous, thus allowing studies on a wide variety of foods. This makes it possible to test a nutrient source as the sole dietary component and avoid 
associated effects which are inevitable if the food is provided in a mixture. The rat can thus, with high accuracy, predict how much of a nutrient in a food source is biologically available, and earlier data demonstrate good agreements between man and the rat (FAO/WHO, 1991). Since differences in the nutritive value of foods are, to a great extent, due to differences in digestibility, the rat will help to bridge the gap between chemical measurements and costly biological experiments performed on humans. Therefore, a joint FAO/WHO expert consultation recommended the use of the rat balance method for predicting protein digestibility in man (FAO/WHO, 1991).

Comparative digestibility studies performed on man and the rat with identical diets are scarce. In a study with young adults, growing pigs and Sprague-Dawley rats Forsum et al. (1982) measured the true protein digestibility of three different diets. The agreement between man and the rat was extremely good while the values obtained on pigs were somewhat different. In an earlier study the same agreement for true protein digestibility and digestible energy between man and the rat was not seen (Forsum et al. 1981). An excellent agreement between man and the rat in apparent protein digestibility of six diets was also demonstrated by Rich et al. (1980). Based on the results obtained the authors concluded that the ability of man and the rat to digest this broad range of food proteins was identical. This holds for legume-based as well as non-legume-based diets. Protein digestibility results obtained using the rat were, in most cases, directly applicable to man and pigs.

The degradation of dietary fibre (DF: non-starch polysaccharides (NSP) plus lignin) from wheat bran, apple, cabbage, carrot and guar gum in the gastrointestinal (GI) tract of man and the rat was compared by Nyman et al. (1986). There was in general a good agreement in the degradation of DF polysaccharides between the two species ( $r 0.99$, regression coefficient 0.86 ). The authors concluded that the rat is useful for the prediction of fermentative breakdown and bulking capacity of various DF sources for man. However, there are differences in the gut physiology of man and the rat. The rat can practise coprophagy and has a relatively big caecum that may be of importance for the bacterial degradation of DF (Van Soest et al. 1982). Van Soest et al. (1982) have done comparative studies on the fermentation of DF in man and animals, and concluded that in man it was more extensive than in the rat but less than that in pigs.

The aim of the present study was to compare the digestibility in man and the rat of energy, protein fat and NSP in mixed diets with added DF from fruits and vegetables (Study 1), citrus fruits (Study 2) and barley (Study 3). The studies on man took place in Kiel, Germany, while the rat studies were performed at Foulum, Denmark.

\section{MATERIALS AND METHODS: HUMAN STUDIES}

\section{Subjects}

A total of thirty healthy, free-living female students aged 22-28 years took part in the balance experiments. Informed written consent was obtained from all volunteers. The studies were approved by the Ethical Committee of the Medical Faculty of the University of Kiel. Normal energy intake of each subject was calculated from a $7 \mathrm{~d}$ prestudy record using a German food table (Deutsche Forschungsanstalt für Lebensmittelchemie, 1986). During the studies, subjects had a controlled food intake that maintained their body weight in a range of $\pm 1 \mathrm{~kg}$. The subjects had lunch together in the institute kitchen, foods for all other meals were prepackaged and consumed at home.

\section{Study plan}

Three studies with a total of seven experimental periods were performed. Details of the study design are shown in Table 1. During the last week of each experimental period, balances were performed. 
Table 1. Plan of the human experiments

\begin{tabular}{lccc}
\hline \multicolumn{1}{c}{ Study ... } & 1 & 2 & 3 \\
\hline $\begin{array}{l}\text { Fibre source studied } \\
\text { No. of experimental periods }\end{array}$ & Fruits/vegetables & Citrus fibre & Barley fibre \\
$\begin{array}{l}\text { Duration of each experimental period } \\
\text { (weeks) }\end{array}$ & 2 & 2 & 3 \\
$\begin{array}{l}\text { Time between experimental periods } \\
\text { (weeks) }\end{array}$ & 3 & 4 & 3 \\
$\begin{array}{l}\text { No. of subjects } \\
\text { Study design }\end{array}$ & 6 & 4 & 3 \\
& $\begin{array}{c}\text { Low-fibre diet followed } \\
\text { by high-fibre diet }\end{array}$ & Cross over & $3 \times 3$ Cross over \\
\hline
\end{tabular}

Table 2. Daily intake $(\mathrm{g} / \mathrm{d})$ of fibre-containing foods from a 2 d rotating menu by human subjects during Study 1 (fruits and vegetables)*

\begin{tabular}{|c|c|c|c|c|c|}
\hline & \multicolumn{2}{|c|}{ Day 1} & & \multicolumn{2}{|c|}{ Day 2} \\
\hline & $\begin{array}{c}\text { Low-fibre } \\
\text { diet }\end{array}$ & $\begin{array}{l}\text { High-fibre } \\
\text { diet }\end{array}$ & & $\begin{array}{c}\text { Low-fibre } \\
\text { diet }\end{array}$ & $\begin{array}{l}\text { High-fibre } \\
\text { diet }\end{array}$ \\
\hline Cake & 60 & - & Cake & 60 & - \\
\hline White bread & 100 & 25 & White bread & 100 & 25 \\
\hline Rye mixed bread & 100 & - & Rye mixed bread & 100 & - \\
\hline Whole grain rye bread & - & 200 & Whole grain rye bread & - & 200 \\
\hline Potatoes & 100 & 100 & Potatoes & 100 & 100 \\
\hline Carrots (cooked) & 200 & 200 & Red cabbage & 200 & 200 \\
\hline Tomato & 60 & 60 & Cucumber & 50 & 50 \\
\hline Orange & 150 & 200 & Apple & 150 & 250 \\
\hline Apple & - & 200 & Pear & - & 250 \\
\hline Brussel sprouts & - & 200 & Dried peas (cooked) & $\ldots$ & 100 \\
\hline Canned peas & - & 100 & Green beans & - & 210 \\
\hline Kidney beans (cooked) & - & 100 & White cabbage & 一 & 100 \\
\hline
\end{tabular}

Rye mixed bread, low extraction rye and wheat flour $(60 ; 40, \mathrm{w} / \mathrm{w})$.

* Diets were consumed in rotation for 3 weeks in each experimental period. Each subject consumed the same amount of fibre-containing foods. The consumption of fibre-free foods (meat balls, sausage, cheese, pudding, margarine) corresponded to individual energy requirements but was kept constant for each subject during both experimental periods of Study 1. For further details of study design, see pp. 472-473.

\section{Diets}

During each experimental period the intake of the basal diet which was composed of DFcontaining foods was the same for all subjects, whereas DF-free foods were provided in an amount that covered individual energy requirements. All food consumed during the experiments was prepared in the institute kitchen and was weighed to the nearest $\mathrm{g}$.

Study 1. During both experimental periods, two $1 \mathrm{~d}$ menus of similar composition were given in rotation. The low DF control diet and the high DF diet differed mainly in their content of fruits and vegetables. DF-free foods were the same in both periods. The intake of DF-containing foods is given in Table 2. Briefly, the consumption of fruits and vegetables increased by $730 \mathrm{~g} / \mathrm{d}$, corresponding to an increased NSP intake from $17.5 \mathrm{~g} / \mathrm{d}$ to $49 \cdot 0 \mathrm{~g} / \mathrm{d}$, when the high $\mathrm{DF}$ diet was consumed.

Study 2. Two DF-containing menus of similar composition were given in rotation during each experimental period. All subjects consumed the same amount of these foods. When 
Table 3. Daily intake $(\mathrm{g} / \mathrm{d})$ of fibre-containing foods from a 2 d rotating menu by human subjects during Study 2 (citrus fibre)*

\begin{tabular}{lclc}
\hline \multicolumn{1}{c}{ Day 1 } & & \multicolumn{2}{c}{ Day 2 } \\
\hline Wheat/rye mixed bread $\dagger$ & 300 & Wheat/rye mixed bread $\dagger$ & 300 \\
Tomato soup $\dagger$ & 210 & Chicken soup $\dagger$ & 210 \\
Mashed potatoes $\dagger$ & $205 / 230 \dagger$ & Mashed potatoes $\uparrow$ & $205 / 230 \ddagger$ \\
Cucumber & 150 & Chinese leaves & 40 \\
Strawberries & 150 & Orange & 150 \\
'Quark' $\dagger$ & $118 / 155 \ddagger$ & 'Dickmilch' $\dagger$ & $118 / 155 \ddagger$ \\
Orange juice $\dagger$ & 500 & Maracuia juice $\dagger$ & 500 \\
\hline
\end{tabular}

Wheat mixed bread, low extraction wheat and rye flour $(60: 40)$; rye mixed bread, low extraction rye and wheat flour $(60: 40, \mathrm{w} / \mathrm{w})$; 'Quark', cottage cheese; 'Dickmilch', yoghurt; Maracuia juice, passion fruit juice.

* Each subject consumed the same amount of these foods daily during the low-fibre and the high-fibre periods, respectively. In addition cheese, sausage, pudding, margarine, honey and marmalade were consumed. The intake of these foods depended on the individual energy requirement but was kept constant for each subject during the experiments.

$\dagger$ Foods were enriched with citrus fibre during the high-fibre period.

\$ Weight of foods was increased during the high-fibre period because additional water was added.

the high DF diet was consumed, $35 \mathrm{~g}$ of a citrus fibre concentrate (CitroFibre DF-50; Citrosuco S/A, Matao, Brazil) providing $20.2 \mathrm{~g} \mathrm{NSP} / \mathrm{d}$ was added to bread, 'Quark' (cottage cheese), 'Dickmilch' (yoghurt), mashed potatoes, soup and juice. During the low DF diet these foods were consumed without added DF (Table 3). In addition, DF-free foods were consumed corresponding to individual energy requirements.

Study 3. The diets consisted of a low DF control diet and two high DF diets with added insoluble DF from barley. When the high DF diets were consumed, $23 \mathrm{~g}$ barley fibre concentrate (Gastrex; ALKO AB, Rajamäki, Finland), corresponding to $15 \mathrm{~g} \mathrm{NSP}$, was incorporated into $300 \mathrm{~g}$ wheat mixed bread (low extraction wheat and rye flour, $60: 40, \mathrm{w} / \mathrm{w}$ ) consumed daily by each subject. In the low DF diet $200 \mathrm{~g}$ of wheat mixed bread without added DF and $60 \mathrm{~g}$ cake were eaten. In one experimental period on the high DF diet parts of animal foods were replaced by low DF plant foods in order to decrease the intake of protein. The intake of DF-containing foods is shown in Table 4.

\section{Balance technique}

Balances were performed during the last week of each experimental period. Duplicates of all foods consumed were weighed, homogenized and kept frozen until freeze dried. Faeces were collected separately in plastic pots that were immediately transferred to the laboratory, weighed and frozen. Acid brilliant green (E142) in a gelatine capsule was given as a faecal marker at the beginning and the end of each collection period. After each balance period faeces were thawed, pooled together, homogenized and one sample was freeze-dried.

\section{MATERIALS AND METHODS: RAT STUDIES}

\section{Study design}

The general experimental procedure has been described by Eggum (1973). Groups of either five (Study 1) or six (Studies 2 and 3) male Wistar rats were used per diet. They weighed approximately $70 \mathrm{~g}$ when the experiment started. A preliminary period of $17 \mathrm{~d}$ and a balance period of $5 \mathrm{~d}$ were used. The rats gained about $130 \mathrm{~g}$ in this period. The rats were all fed ad lib. Diet formulation was as given for the human studies. 


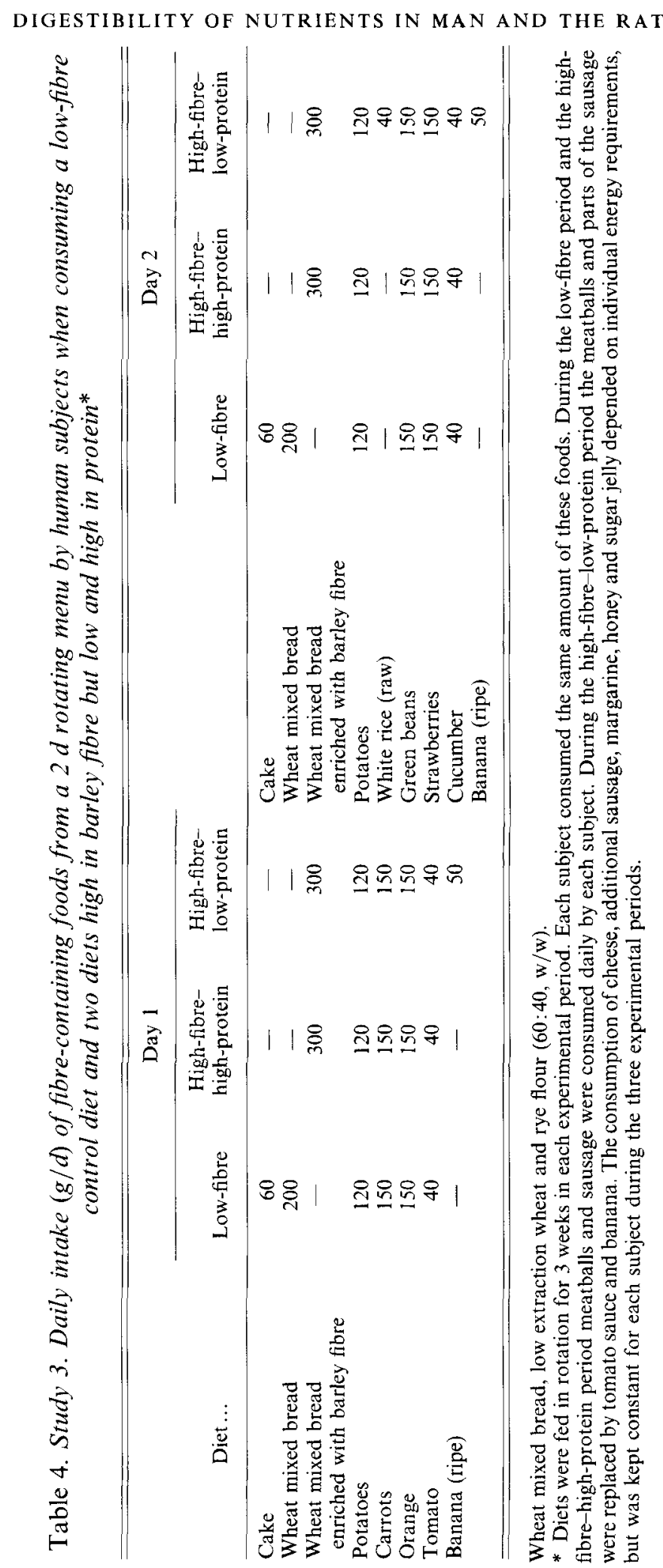




\section{Diets}

During the balance periods of each study in humans, duplicate samples of the basal diets and of the additional foods consumed by the individual subjects were collected, mixed together, homogenized, lyophilized, ground to pass a $1 \mathrm{~mm}$ mesh screen and kept frozen until used as diets for the rats. Thus, the rat diets corresponded to the average food and nutrient intake of the human subjects during each experimental period. The chemical composition of the experimental diets is given in Table 5.

\section{Chemical analyses}

Dry matter. Dry matter content of food and faeces was determined by drying the freezedried samples at $105^{\circ}$ for $8 \mathrm{~h}$.

Gross energy. Gross energy was determined in the freeze-dried samples of foods and faeces by adiabatic bomb calorimetry using an IKA calorimeter C 400 (Jahnke \& Kunkel, IKA-Werk, Heitersheim, Germany) in the human studies and a LECO AC 300 automated calorimeter system 789-500 (LECO, St. Joseph, Michigan, USA) in the rat studies.

Protein. N was determined by a micro-Kjeldahl method in human studies (Arbeitsgemeinschaft-Getreideforschung, 1978) and in the rat experiments by the Kjeldahl method using a Kjell-Foss 16200 autoanalyser. Protein was calculated as $\mathrm{N} \times 6.25$.

Fat. Fat was determined after hydrolysis by extraction with light petroleum (b.p. $40-60^{\circ}$ ) in human studies and with diethyl ether in rat studies (Stoldt, 1952).

NSP. Total NSP and their constituent sugars in diets and faeces were determined as alditol acetates by GLC for neutral sugars using the Uppsala procedure C (Theander \& Westerlund, 1986) in human studies and a modification of the Uppsala (Theander \& Åman, 1979; Theander \& Westerlund, 1986) and the Englyst (Englyst et al. 1982) procedures in rat studies (Bach Knudsen et al. 1993) and by a colorimetric method for uronic acids (Scott, 1979). In principle, the determination of NSP in human and rat studies differed in the concentration of $\mathrm{H}_{2} \mathrm{SO}_{4}$ used and the time and temperature used for the hydrolysis of the polysaccharides. Starch was quantitatively removed by incubation $\left(100^{\circ}, 60 \mathrm{~min} ; 60^{\circ}, 16 \mathrm{~h}\right)$ with a thermostable $\alpha$-amylase $\left(E C\right.$ 3.2.1.1; Termamyl ${ }^{\circledR}$; Novo Nordisk A/S, Copenhagen, Denmark) and with a $\beta$-glucanase-free amyloglucosidase (EC 3.2.1.3; cat. no. 124001; Boehringer Mannheim GmbH, Mannheim, Germany). The soluble NSP was precipitated with ethanol $(800 \mathrm{ml} / 1)$. In the human studies the NSP in faeces was determined without prior starch removal. The polysaccharides in the starch-free residues were allowed to swell in the presence of $\mathrm{H}_{2} \mathrm{SO}_{4}\left(12 \mathrm{M}, 30^{\circ}, 60 \mathrm{~min}\right)$. Hydrolyses were performed with $0.41 \mathrm{M} \mathrm{H}_{2} \mathrm{SO}_{4}\left(125^{\circ}, 1 \mathrm{~h}\right)$ in human studies and with $1 \mathrm{M} \mathrm{H}_{2} \mathrm{SO}_{4}\left(100^{\circ}, 2 \mathrm{~h}\right)$ in the rat studies. Neutral sugars were reduced with potassium borohydride to alcohols and acetylated with 1-methylimidazole to catalyse the reaction. Myoinositol was used as internal standard in human studies and allose was used in rat studies. Corrections for hydrolytic losses and detector response were made by performing the analysis with known sugar standards. The procedures for measuring NSP residues, although slightly different at the two institutes, gave comparable results. This is documented by the results from Study 3 (Table 6).

Klason lignin. Klason lignin was measured gravimetrically as the residue resistant to $12 \mathrm{M}_{-} \mathrm{H}_{2} \mathrm{SO}_{4}$ (Theander \& Äman, 1979; Theander \& Westerlund, 1986).

\section{Calculations and statistical analyses}

The content of polysaccharide residues in food and faeces was calculated as anhydrosugars, and all digestibilities (apparent digestibility of protein (ADP), digestibility of fat, digestibility of NSP and digestibility of energy (DE)) were calculated on the basis of the 


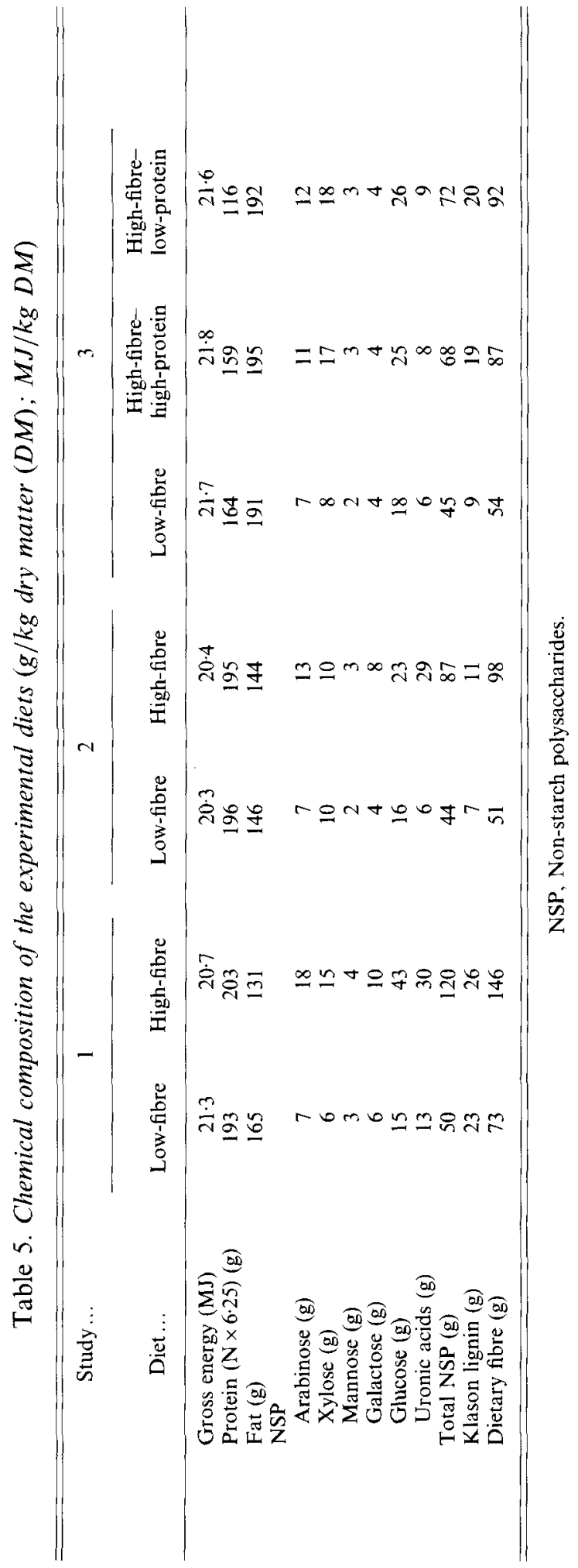


Table 6. Average values ( $\mathrm{g} / \mathrm{kg}$ dry matter) for the measurement of non-starch polysaccharides (NSP) of the diets used in Study 3 (barley fibre) at the two institutes

\begin{tabular}{|c|c|c|c|c|c|c|}
\hline \multirow{2}{*}{$\begin{array}{l}\text { Diet ... } \\
\text { Institute... }\end{array}$} & \multicolumn{2}{|c|}{ Low-fibre } & \multicolumn{2}{|c|}{ High-fibre-high-protein } & \multicolumn{2}{|c|}{ High-fibre-low-protein } \\
\hline & Kiel & Foulum & Kiel & Foulum & Kiel & Foulum \\
\hline Arabinose & 6 & 7 & 12 & 11 & 12 & 12 \\
\hline Xylose & 8 & 8 & 20 & 17 & 20 & 18 \\
\hline Mannose & 2 & 2 & 2 & 3 & 2 & 3 \\
\hline Galactose & 5 & 4 & 6 & 4 & 6 & 4 \\
\hline Glucose & 15 & 18 & 23 & 25 & 24 & 26 \\
\hline Uronic acids & 8 & 6 & 8 & 8 & 8 & 9 \\
\hline Total NSP & 44 & 45 & 71 & 68 & 72 & 72 \\
\hline
\end{tabular}

recorded quantitative intake and excretion in faeces. The faecal bulking capacity and its composition when adding the DF sources in all three studies were calculated as the increase in faecal NSP, protein, fat and residues/g increase in ingested NSP. The results from studies 1-3 within each dietary treatment group were initially examined by a one-way analysis of variance model (Snedecor \& Cochran, 1973):

$$
X_{i j}=\mu+\alpha_{i}+\epsilon_{i j}
$$

where $X_{i j}$ is the dependent variable (e.g. NSP constituent sugar values), $\mu$ is the overall mean, $\alpha_{i}$ is the effect of species (man or rat) and $\epsilon_{i j}$ is a normally distributed random variable. All statistical calculations were done by GLM (General Linear Modeling) using a SuperANOVA package (ABACUS Concepts, Berkeley, CA, USA).

\section{RESULTS}

\section{Study $1:$ diets rich in fruits and vegetables}

In the low DF diet DE was the same for both rat and man, while in the high DF diet DE was significantly $(P<0.01)$ higher for man than for the rat (Table 7$)$. However, ADP did not differ between man and rat on either diet irrespective of the DF level. There was a lower digestibility, although not significant, of total NSP in the rat than in man on the low DF diet while the difference between man $(0.734)$ and the rat $(0.597)$ on the high DF diet was significant $(P<0.05)$. Of the NSP residues in the low DF diet only xylose was digested significantly better in man than in the rat, whereas on the high DF diet all constituent sugars with the exception of arabinose and galactose were degraded more completely in man than in the rat.

\section{Study 2: diets with added citrus fruit $D F$}

DE was the same for both species at the low DF level, while at the high DF level DE was significantly lower for the rat than for man with values of 0.906 in the rat compared with 0.931 in man $(P<0.01$; Table 8$)$. There was no difference with regard to the digestibility of protein between the two species. Digestibility of fat was not significantly different between man and the rat on the low DF intake level but on the high DF intake level digestibility was 0.948 in man compared with 0.959 in the rat $(P<0.01)$. The digestibility of total NSP and its residues was consistently and significantly $(P<0.001)$ lower in the rat than in man. For the low DF diet the digestibility of total NSP was 0.774 in man compared with only 0.501 in the rat. The biggest difference was seen for xylose and the smallest 

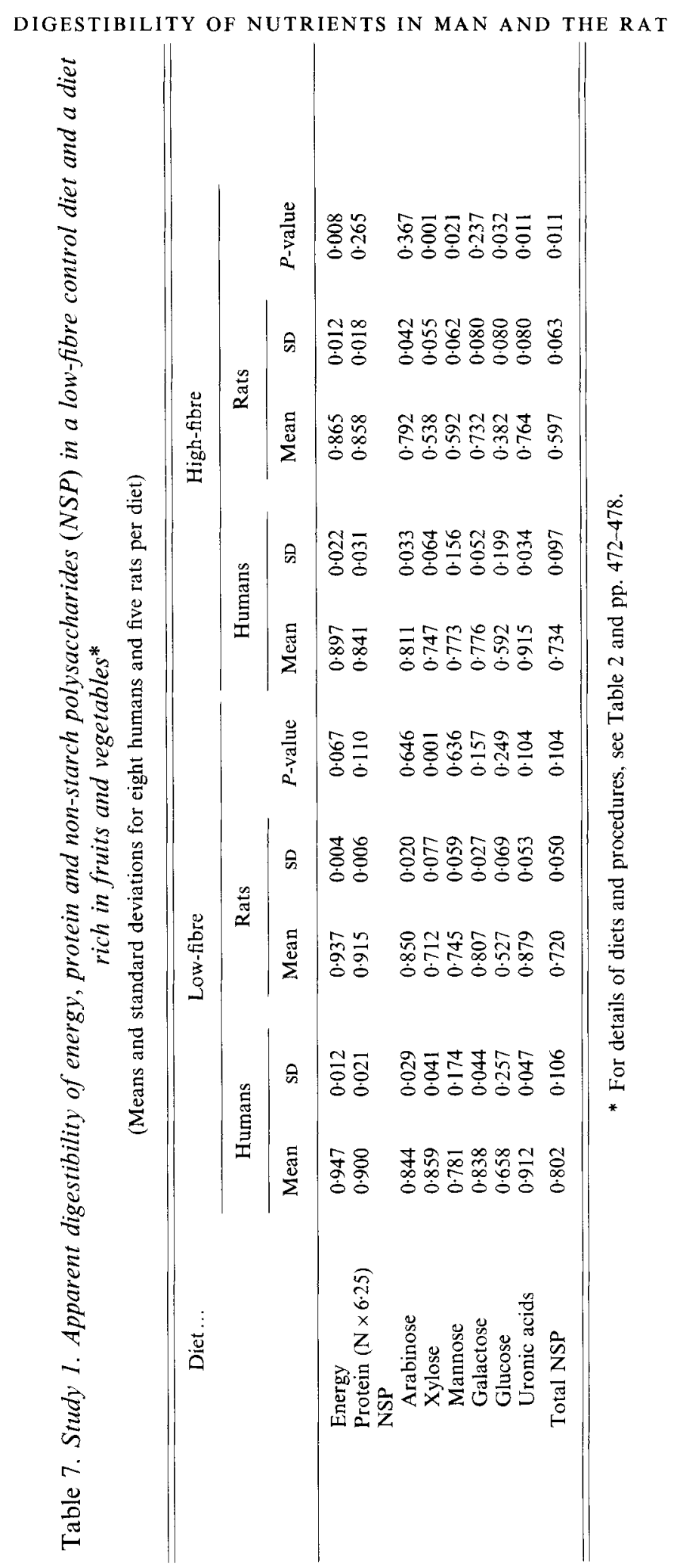


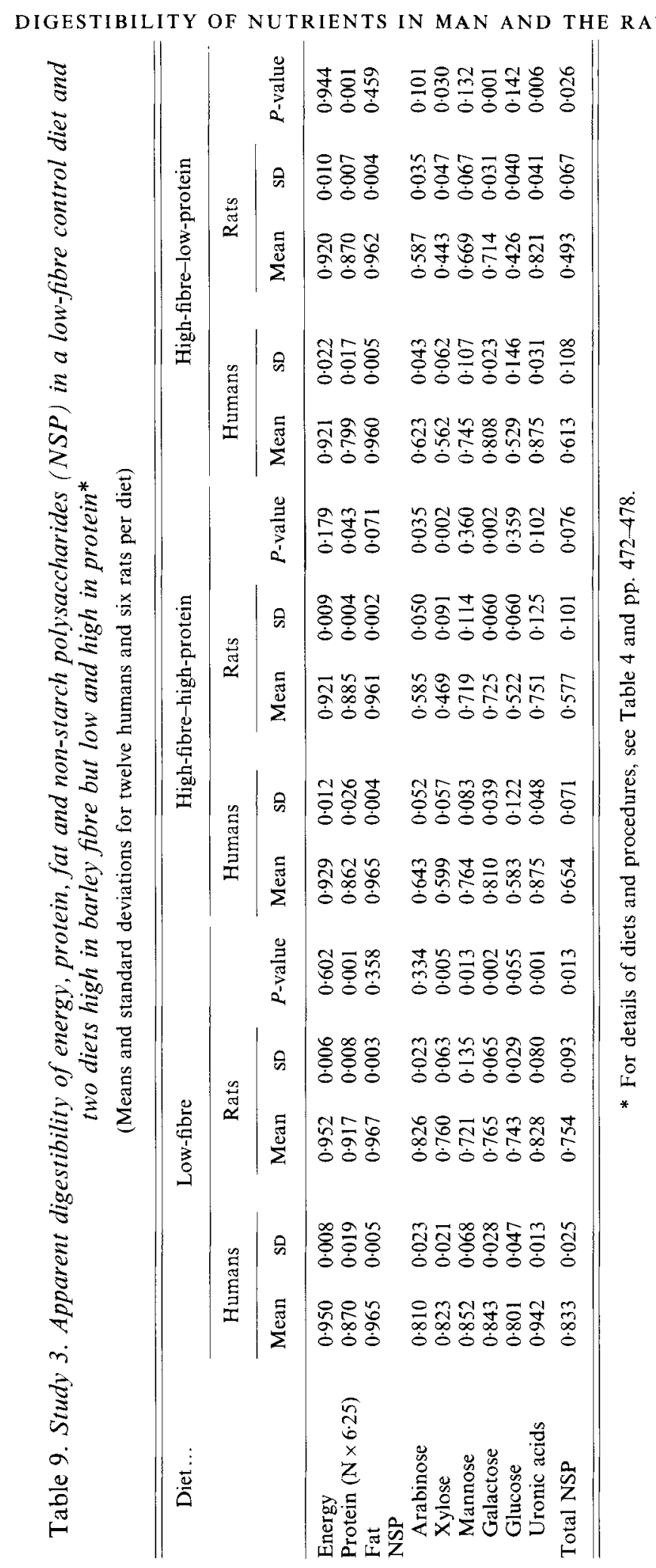




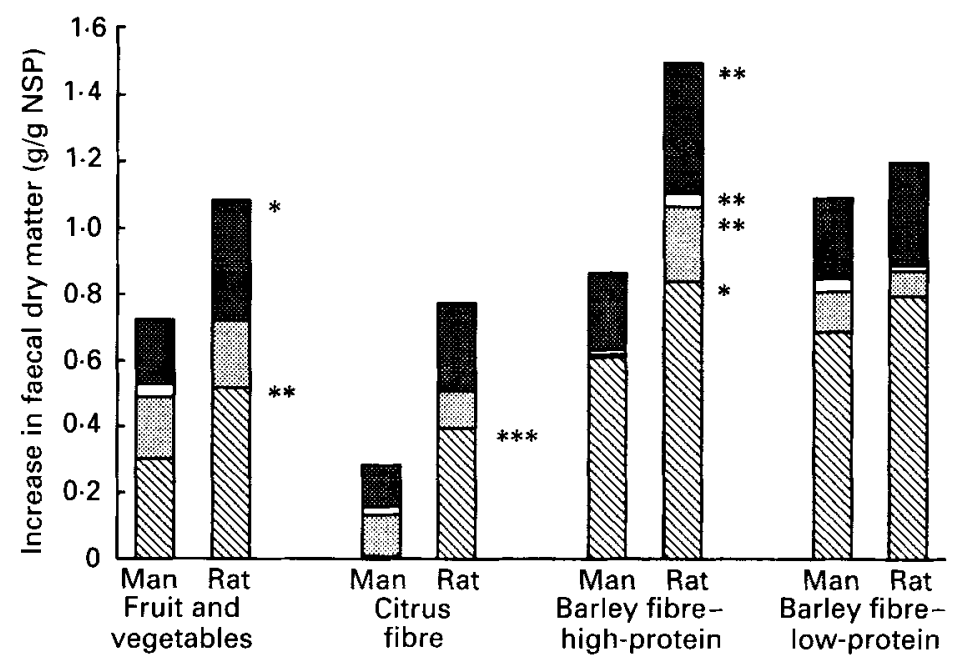

Fig. 1. Effect of the various dietary fibre sources on faecal dry matter bulking and its composition in man and the rat. The values are expressed as $g$ increase in non-starch polysaccharides (NSP) (\$), protein $(\mathrm{N} \times 6.25)($ 䀡), fat $(\square)$ and residues $(\square)$ per $g$ increase in NSP intake. ${ }^{*} P<0.05 ;{ }^{* *} P<0.01$; ${ }^{* * *} P<0.001$.

difference for arabinose. The differences in digestibility of total and NSP residues were in general higher at the high DF level. The digestibility of total NSP was 0.885 in man compared with 0.517 in rat. Glucose was the NSP residue with the biggest difference, and arabinose the NSP residue with the smallest difference.

\section{Study 3: diets enriched with barley DF at two protein levels}

$\mathrm{DE}$ was high for all three diets and the same for man and the rat with no significant differences (Table 9). However, ADP was consistently higher in the rat than in man. This was especially pronounced on the high $\mathrm{DF}$-low protein diet where the difference between man and rat was 0.071 absolute units $(P<0.001)$. In contrast, there was no difference in the digestibility of fat between the two species. The digestibility of total NSP on the control diet was significantly $(P<0.05)$ lower when measured in the rat $(0.754)$ than in man $(0.833)$. The same was the case with the high DF-low protein diet, while the difference was much smaller with the high DF-high protein diet $(P<0.08)$. Consistent with the results for total NSP most NSP residues were more completely degraded in man than in the rat. However, the differences between the two species were not always significant.

\section{Faecal bulking capacity}

The faecal dry weight increment due to DF was higher in the rat than in man for all the DF sources except when the barley DF was fed at the low protein level (Fig. 1). On the barley DF-high protein diet there was a higher faecal protein excretion in the rat than in man, whereas on the barley DF-low protein diet and the citrus DF diet faecal protein losses were lower in the rat than in man, while on the fruit and vegetable diet there were no differences in the increment in faecal protein due to the ingestion of DF. The increase in faecal fat in response to adding fibre was about the same in the two species.

\section{DISCUSSION}

Comparative studies at different institutes are difficult as they require a high degree of standardization of, among other things, the analytical methods. In our study we have tried to eliminate as many confounding factors as possible which may influence digestibility 
estimations in two species at two different institutes. The analytical methods for $\mathrm{N}$, energy and fat were based on standard procedures and gave comparable results at the two institutes. This was also true for the procedure for measuring NSP residues, the only chemical method used in this study where no agreed standard procedure is available yet, as all diets gave comparable results. In this respect our study had a higher degree of standardization than the study of Nyman et al. (1986) where table values were used to estimate intake of NSP residues in man, whereas faecal NSP residues were analysed using the method of Englyst et al. (1982). Intake and faecal excretion of NSP residues in the rat studies were measured analytically by the method of Theander \& Åman (1979).

The present study shows good agreement as well as significant differences in the absolute values for the digestibility of energy, protein and NSP between man and rat whereas the digestibility of fat was very similar for the two species. Digestibility of energy was in general higher in man than in the rat with the biggest differences on diets high in DF with absolute values of 0.032 in Study 1 and 0.025 in Study 2. Both of these differences were significant. On the other diets there were no significant differences in energy digestibility between the two species. Our studies thus are in good agreement with the values obtained with man and the rat by Forsum et al. (1981) using a vegetable protein diet and a vegetable-animal protein diet. These authors found no significant differences in the digestibility of energy of the diets although there was a tendency to higher values obtained in man. The reason for this is probably a higher capacity to ferment DF in man than in the rat.

In contrast to the digestibility of energy, ADP had a tendency to be lower when measured in man compared with the rat in Studies 1 and 2, although the values were not significantly different between the species. This is in accordance with the work of Rich et al. (1980) who measured ADP of a great variety of foods in both man and rat. Based on their findings the authors concluded that the ability of man and the rat to digest protein is the same. Forsum et al. (1982) measured the true protein digestibility of two mixed diets and a diet with egg white in rats, man and pigs. The values obtained in man and rats were almost identical while the values for pigs deviated more. In Study 3, with barley DF as the DF source, the rat, however, digested the protein significantly better than man. With the high DF-low protein diet the difference between the two species was 0.071 absolute units. Although significant, the differences in ADP on the two other diets in Study 3 were much smaller. It should be mentioned that Forsum et al. (1981) also measured true protein digestibility to be lower on a vegetable protein diet when measured in man compared with the rat. On the other hand, true protein digestibility was the same for man and rat on a vegetable-animal protein diet. This seems to indicate that the type of DF might affect protein digestibility differently in man and the rat.

In comparison with faecal protein, losses of fat are small both in man and in the rat and appear to depend mainly on the amount (Kasper, 1970; Apgar et al. 1987) and sometimes also on the type of fat ingested (Chen et al. 1987; De Schrijver et al. 1992). An increased fat intake caused higher faecal fat excretion in both species (Walker et al. 1973; Apgar et al. 1987), but had in most experiments no effect on apparent digestibility of dietary fat (Walker et al. 1973; De Schrijver et al. 1992). Apparent digestibility of fat may also depend on the DF content of the diet. NSP which form viscous solutions, but also some other DF, can cause higher faecal lipid losses both in man and in the rat (Southgate \& Durnin, 1970; Mokady, 1973; Prynne \& Southgate, 1979) and thereby a decreased fat digestibility. In contrast to protein digestibility, the influence of DF on apparent fat digestibility seems not to be related to fibre fermentation, but to an interference with the digestion and absorption of dietary fat in the small intestine (Vahouny \& Cassidy, 1987).

In the present work, types of dietary fibre and fat as well as their contents in the diets were the same for man and rat during each study, and there were also only marginal 
differences in apparent fat digestibility between man and rat. Therefore, it may be assumed that under the conditions of our studies the absorption and excretion of fat were comparable between man and rat.

The results of this study are inconsistent with an earlier study of Nyman et al. (1986) who found a good correlation between digestibilities of NSP residues in man and the rat. Technical differences in the way the balance trials were performed may be the reason. In our study we estimated the digestibility of NSP residues in mixed diets, while in the study of Nyman et al. (1986) the DF sources were ingested in addition to a low DF basal diet in the human experiments (Cummings et al. 1978), whereas in the rat studies DF sources were added to a semipurified diet to give a final DF level of $100 \mathrm{~g} / \mathrm{kg}$ (Nyman et al. 1986). Another factor that could have had a contributing effect is the duration of the preliminary period. In our study we used a preliminary period of $17 \mathrm{~d}$ in the rat studies while Nyman et al. (1986) only used $4 \mathrm{~d}$.

The lower digestibility of NSP residues in rat than in man can be related to differences in gut physiology and consequently transit time (TT). The rat is mainly a caecum fermenter, in contrast to man where the fermentative capacity of the caecum is insignificant compared with that of the colon. It is also well established that the rat, like other small animals, needs more energy per unit body-weight which will inevitably influence the TT through the large bowel, thus leaving less time for microbial fermentation of NSP residues (Van Soest et al. 1982). Mean transit time (MTT) through the whole gut for the human subjects given the low DF control diets will probably be $58-76 \mathrm{~h}$ as found in other studies with typical western-style diets (Cummings et al. 1976; Spiller et al. 1986; Stevens et al. 1987). This figure may decrease to $38-59 \mathrm{~h}$ when the DF intake reaches $35-50 \mathrm{~g} / \mathrm{d}$ (Cummings et al. 1976; Spiller et al. 1986; Stevens et al. 1987). Most current data indicate that MTT in the rat is lower; $32-52 \mathrm{~h}$ at a DF intake of 0.4-0.5 g/d (Raczynski et al. 1982; Bach Knudsen et al. 1991; Hansen et al. 1992) and 22-32 h at a DF intake of $1.5-1.7 \mathrm{~g} / \mathrm{d}$ (Raczynski et al. 1982; Bach Knudsen et al. 1991; Hansen et al. 1992).

Many studies of plant cell-wall fermentation have established that this is a relatively slow process (Van Soest, 1975; Van Soest, 1984). Supposing TT to be the limiting factor for the digestibility of NSP residues, one would have expected the biggest difference in the digestibility of NSP between the two species to occur at the high DF intake level, or when feeding the DF source most resistant to digestion. This was not, however, the case. In this investigation we found a bigger difference between man and the rat in Study 2 and in Study 3. The DF source in Study 2 was in the form of citrus DF which has a high pectin content, whereas in Study 3 insoluble barley DF in the form of cellulose and hemicellulose was used to increase the DF level. In vitro and in vivo fermentation studies have shown that isolated pectin is an easily degradable DF source for the microflora (Nyman \& Asp, 1982) while insoluble barley DF in the form of cellulose and hemicellulose is far less degradable (Bach Knudsen et al. 1991).

Species differences in level and composition of the microflora between man and the rat may be another factor that may influence the digestibility of NSP residues. The responses of the individual species of the gut flora in different animal species to changes in nutrient supply are largely unknown, primarily because of the complexity of this ecosystem. The microbial population that inhabits the human colon is a large (about $10^{11}$ viable counts $/ \mathrm{g}$ content) and highly complex community comprising 400-500 bacterial species (Macfarlane \& Cummings, 1991). The bacterial population in the caecum and colon of the rat is not so well described but it would probably reach the same level as in man (about $10^{11}$ viable counts/g content; B. O. Eggum, B. B. Jensen and K. E. Bach Knudsen, unpublished results). However, at the species level the flora of the rat is probably different to that of man. According to Moore et al. (1987) there is now increasing evidence that each animal 
species including man carries a flora distinct from that found in other animals. The authors believe that this is a result of natural selection, which provides protection for different animals. The fewer the bacterial species that different animals share, the less the likelihood of disease transmission between animal species.

The more extensive degradation of NSP residues in man than in the rat also has implications for $\mathrm{N}$ metabolism in the large bowel of the two species. It is well known that the largest part of faecal $\mathrm{N}$ is incorporated into bacterial residues and that the microflora of the large bowel is metabolically very active and is able to assimilate both exogenous and endogenous $N$. Nutritional factors that are known to influence large bowel fermentation are the type and amount of residues passing into the large bowel. It has been shown in both man and the rat that a more extensive microbial fermentation of dietary residues is inevitable followed by a higher excretion of microbial faecal N (Mason \& Palmer, 1973; Stephen \& Cummings, 1980). In good agreement with these findings we found the lowest digestibility of protein in man which also has the highest digestibility of NSP.

In man (Stephen \& Cummings, 1980), but probably also in the rat, most of the faecal fat is part of the bacterial mass. In studies with rumen bacteria it was shown that the lipid content of bacteria showed species differences and that it was also dependent on the exogenous supply of fat (Czerkawski, 1976). If the same is true for bacteria of the large intestine, their fat content may depend on the amount of fat not absorbed in the small intestine. Therefore, unlike faecal protein, the amount of faecal fat will not correlate with the fermentation of DF and the amount of bacteria resulting from this process. This is in accordance with our results as there were only small differences in apparent digestibility of dietary fat between man and the rat despite a higher DF fermentation in man.

It is somewhat disconcerting to find that for several of the diets the rat digested NSP residues to a much lower extent than man. This has a direct effect on the bulking capacity and apparent digestibility of protein which are higher in the rat than in man, and on the digestibility of energy which is slightly lower or the same in the two species. The best agreement between man and the rat was found for the digestibility of fat which was about the same. The results of our study, thus, favour the view of Van Soest et al. (1982) that larger animals such as man and the pig digest DF polysaccharides to a greater extent than smaller animals such as the rat. The results are further evidence for those who advocate that absolute digestibility values have to be estimated on the species in question. It is, however, noticeable that the rat and man rank the different diets in the same order. It should also be stressed that our study, together with most of the literature values referred to, demonstrates a very good agreement between man and the rat when considering energy, protein and fat digestibility. The observed deviations seem to be due to a different capacity in man and rat to ferment DF which inevitably will have an influence on the digestibility of protein and energy. However, the similar capacity of man and rat to digest protein supports the recommendation made by FAO/WHO (1991) in recommending the use of the rat for predicting true protein digestibility in man.

\section{REFERENCES}

Apgar, J. L., Shively, C. A. \& Tarka, S. (1987). Digestibility of cocoa butter and corn oil and their influence on fatty acid distribution in rats. Journal of Nutrition 117, $660-665$.

Arbeitsgemeinschaft-Getreideforschung (1978). Standardmethoden für Getreide, Mehl und Brot, Schäfer (Standard methods for grain, flour and bread). Detmold, Germany: Schäfer.

Bach Knudsen, K. E., Agergaard, N. \& Olesen, H. P. (1991). Effect of caecectomy and transit time on digestibility of plant polysaccharides and of amino acids in rats. Journal of Animal Physiology and Animal Nutrition 66, 190-203.

Bach Knudsen, K. E., Jensen, B. B. \& Hansen, I. (1993). Digestion of polysaccharides and other major components in the small and large intestine of pigs fed diets consisting of oat fractions rich in $\beta$-D-glucan. British Journal of Nutrition $70,537-556$. 
Chen, I. S., Hotta, S. S., Ikeda, I., Cassidy, M. M., Sheppard, A. J. \& Vahouny, G. V. (1987). Digestion, absorption and effects on cholesterol absorption of menhaden oil, fish oil concentrate and corn oil by rats. Journal of Nutrition 117, 1676-1680.

Cummings, J. H., Jenkins, D. J. A. \& Wiggins, H. S. (1976). Measurement of the mean transit time of dietary residues through the human gut. Gut $17,210-218$.

Cummings, J. H., Southgate, D. A. T., Branch, W., Houston, H., Jenkins, D. J. A. \& James, W. P. T. (1978). Colonic response to dietary fibre from carrot, cabbage, apple, bran and guar gum. Lancet $\mathbf{i}, 5-9$.

Czerkawski, J. W. (1976). Chemical composition of microbial matter in the rumen. Journal of the Science of Food and Agriculture 27, 621-632.

De Schrijver, R., Fremaut, D. \& Verheyen, A. (1992). Cholesterol-lowering effects and utilization of protein, lipid, fiber and energy in rats fed unprocessed and baked oat bran. Journal of Nutrition 122, 1318-1324.

Deutsche Forschungsanstalt für Lebensmittelchemie (1986). Souci. Fachmann. Kraut. Die Zusammensetzung der Lebensmittel. Nährwerttabellen 1986/87 (Souci, Fachmann, Kraut, Nutrition Tables 1986/87) [Deutsche Forschungsanstalt für Lebensmittelchemie, editors]. Stuttgart, Germany: Wissenschaftliche Verlagsgesellschaft.

Eggum, B. O. (1973). A study of certain factors influencing protein utilization in rats and pigs. Report no. 406. Copenhagen: National Institute of Animal Science.

Englyst, H. N., Wiggins, H. S. \& Cummings, J. H. (1982). Determination of non-starch polysaccharides in plant foods by gas-liquid chromatography of constituent sugars as alditol acetates. Analyst 107, 307-318.

Food and Agriculture Organisation/World Health Organisation (1991). Protein Quality Evaluation. Report of Joint FAO/WHO Expert Consultation. FAO Food and Nutrition paper 51. Rome: Food and Agriculture Organization of the United Nations.

Forsum, E., Göranzon, H., Rundgren, M., Thilén, M. \& Hambraeus, L. (1981). Protein evaluation of mixed diets. Comparative study in man and in the pig and rat of vegetable-animal and vegetable protein diets. Nutrition and Metabolism 25, 137-150.

Forsum, E., Göranzon, H. \& Thilén, M. (1982). Protein evaluation of mixed diets in young adults, growing pigs, and growing rats. American Journal of Clinical Nutrition 36, 505-513.

Hansen, I., Bach Knudsen, K. E. \& Eggum, B. O. (1992). Gastrointestinal implications in the rat of wheat bran, oat bran and pea fibre. British Journal of Nutrition 68, 451-462.

Kasper, H. (1970). Fecal fat excretion, diarrhea, and subjective complaints with highly dosed oral fat intake. Digestion 3, 321-330.

Macfarlane, G. T. \& Cummings, J. H. (1991). The colonic flora, fermentation, and large bowel digestive function. In The Large Intestine: Physiology, Pathophysiology, and Disease, pp. 5 I-92 [S. F. Phillips, J. H. Pemberton and R. G. Shorter, editors]. New York: Raven Press Ltd.

Mason, V. C. \& Palmer, R. (1973). The influence of bacterial activity in the alimentary canal of rats on faecal nitrogen excretion. Acta Agricultura Scandinavica 23, 141-150.

Mokady, S. (1973). Effect of dietary pectin and algin on blood cholesterol level in growing rats fed a cholesterolfree diet. Nutrition and Metabolism 15, 290-294.

Moore, W. E. C., Moore, L. V. H., Cato, E. P., Wilkins, T. D. \& Kornegay, E. T. (1987). Effect of high-fiber and high-oil diets on the fecal flora of swine. Applied and Environmental Microbiology 53, 1638-1644.

Nyman, M. \& Asp, N.-G. (1982). Fermentation of dietary fibre components in the rat intestinal tract. British Journal of Nutrition 47, 357-366.

Nyman, M., Asp, N.-G., Cummings, J. H. \& Wiggins, H. (1986). Fermentation of dietary fibre in the intestinal tract, comparison between man and rat. British Journal of Nutrition 55, 487-496.

Prynne, C. J. \& Southgate, D. A. T. (1979). The effects of a supplement of dietary fibre on faecal excretion by human subjects. British Journal of Nutrition 41, 495-503.

Raczynski, G., Eggum, B. O. \& Chwalibog, A. (1982). The effect of dietary composition on transit time in rats. Journal of Animal Physiology and Animal Nutrition 47, 160-167.

Rich, N., Satterlee, L. D. \& Smith, J. L. (1980). A comparison of in vivo apparent digestibility as determined using human and rat pancreatins and commercially available proteases. Nutrition Reports International 21, 285-299.

Scott, R. W. (1979). Colorimetric determination of hexuronic acids in plant materials. Analytical Chemistry 51, 936-941.

Snedecor, G. W. \& Cochran, W. G. (1973). Statistical Methods. Ames: Iowa State University Press.

Southgate, D. A. T. \& Durnin, J. V. G. A. (1970). Calorie conversion factors. An experimental reassessment of the factors used in the calculation of the energy value of human diet. British Journal of Nutrition 24, 517-535.

Spiller, G. A., Story, J. A., Wong, L. G., Nunes, J. D., Alton, M., Petro, M. S., Furumoto, E. J., Whittam, J. H. \& Scala, J. (1986). Effect of increasing levels of hard wheat fiber on fecal weight, minerals and steroids and gastrointestinal transit time in healthy young women. Journal of Nutrition 116, 778-785.

Stephen, A. M. \& Cummings, J. H. (1980). The microbial contribution to human fecal mass. Journal of Medical Microbiology 13, 45-56.

Stevens, J., Van Soest, P. J., Robertson, J. B. \& Levitsky, D. A. (1987). Mean transit time measurement by analysis of a single stool after ingestion of multicolored plastic pellets. American Journal of Clinical Nutrition 46, I048-1054.

Stoldt, W. (1952). Vorschlag zur Vereinheitlichung der Fettbestimmung in Lebensmitteln (Suggestions to standardize the determination of fat in foodstuffs). Fette, Seifen, Anstrichmittel 54, 206-207. 
Theander, O. \& Åman, P. (1979). Studies on dietary fibre. 1. Analysis and chemical characterization of watersoluble and water-insoluble dietary fibres. Swedish Journal of Agricultural Research 9, 97-106.

Theander, O. \& Westerlund, E. A. (1986). Studies on dietary fiber. 3. Improved procedures for analysis of dietary fiber. Journal of Agricultural and Food Chemistry 34, 330-336.

Vahouny, G. V. \& Cassidy, M. M. (1987). Effect of dietary fiber on intestinal absorption of lipids. In $C R C$ Handbook of Dietary Fiber in Human Nutrition, pp. 121-128 [G. A. Spiller, editor]. Boca Raton: CRC Press.

Van Soest, P. I. (1975). Physico-chemical aspects of fibre digestion. In Digestion and Metabolism in the Ruminant, pp. 351-365 [I. N. McDonald and A. C. I. Warner, editors]. Sidney: The University of New England Publishing Unit.

Van Soest, P. J. (1984). Some physical characteristics of dietary fibres and their influence on the microbial ecology of the human colon. Proceedings of the Nutrition Society 43, 25-33.

Van Soest, P. J., Jeraci, J., Foose, T., Wrick, K. \& Ehle, F. (1982). Comparative fermentation of fibre in man and other animals. In Fibre in Human and Animal Nutrition, pp. 75-80 [G. Wallace and L. Bell, editors]. Palmerston North: The Royal Society of New Zealand.

Walker, B. E., Kelleher, J., Davies, T., Smith, C. L. \& Losowsky, M. S. (1973). Influence of dietary fat on fecal fat. Gastroenterology 64, 233-239. 